\title{
Arbuscular mycorrhizal fungi associated with Amaranthus dubius mart.ex thell and Gomphrena globosa L .
}

\author{
C. Hemavani and B. Thippeswamy* \\ Department of P.G. Studies and Research in Microbiology, Bioscience complex, Kuvempu University, Jnana \\ Sahyadri, Shankaraghatta-577 451, Shivamogga (Dist.). Karnataka. INDIA
}

\begin{abstract}
Arbuscular mycorrhizal fungi are found associated with more than $80 \%$ of the plants. But most of the studies show that Amaranthaceae is non mycorrhizal. The present study states the presence of arbuscular mycorrhizal association with Amaranthus dubius Mart ex Thell and Gomphrena globosa L which belong to Amaranthaceae. The plants were screened for the examination of presence of arbuscules, vesicles in the roots and spores in the rhizosphere soil which help to know that mycorrhiza is associated with Amaranthaceae species.
\end{abstract}

Keywords: Arbuscular mycorrhizae; Amaranthaceae; Spores; Arbuscules; Vesicles.

\section{Introduction}

Mycorrhizae is the symbiotic association between fungus and the plant roots. Arbuscular mycorrhizae is associated with more than $80 \%$ of the plants. But few families such as Amaranthaceae, Brassicaceae, Aizoaceae, Cyperacae, Chenopodiaceae and Juncaceae are considered as Non-mycorrhizal (Meada,1954; Harley and Harley,1987). But current study reveals the association of AM fungi with Amaranthaceae. Two plants of Amaranthaceae family Amaranthus dubius Mart ex Thell and Gomphrena globosa L were screened for the presence of AM fungi. In the present study Amaranthus dubius Mart ex Thell and Gomphrena globosa $\mathrm{L}$ are the two plants which were found in the study site. The objective of the study was to see that mycorrhiza is present in the plants which belong to amaranthaceae that was considered as non mycorrhizal.

\section{Material and methods}

\section{Site description}

Bhadra wild life Sanctuary is situated in the midst of Western ghats regions of Chikkamagalore, Narasimharaja pura and Tarikere taluk of Chikkamagalore district and Bhadravathi taluk of Shivamogga district in Karnataka. It covers an area of 492, 46 sq.km. The Sanctuary is situated between $13^{\circ} 25^{\prime}$ and $13^{\circ} 50^{\prime}$ northern latitude and $75^{\circ} 15^{\prime}$ and $75^{\circ} 50^{\prime}$ eastern longitude. The altitude ranges from 670 to $1,875 \mathrm{~m}$ MSL. The temperature in the valley ranges from 10 to $32^{\circ} \mathrm{C}$. Average rain fall during southwest monsoon between June and September is $500-2500 \mathrm{~mm}$. The annual precipitation is 2,000-2,540 $\mathrm{mm}$ and considerably higher than the surrounding plains. The biotic factors and edaphic variations have played a dominant role in determining the forest growth in the sanctuary area.

\section{Soil sampling}

Root samples and rhizosphere soils of two plants from 3 different sites which vary in soil characterstics were collected from Bhadra Wildlife Sanctuary and preserved in sterile polythene bags in refrigerator at $4^{\circ} \mathrm{C}$ until use. Root samples were cut into $1 \mathrm{~cm}$ bits and preserved in FAA until use.

\section{Spore extraction}

The soil samples were subjected to wet-sieving and decanting technique (Gerdmann and Nicolson, 1963) for the isolation of spores. About $100 \mathrm{~g}$ of soil was taken and mixed with was stirred by a blunt glass rod and kept aside for half an hour, till heavier particles settle down. The liquid was passed through the coarse soil sieve. Then the sieve was washed with a stream of water to ensure that all small particles have passed through. The suspension was passed through a sieve fine enough to retain the desired spores. This process was repeated for 4 to 5 times so that the maximum number of spores could be collected. The contents which was retained in these sieves was washed carefully with gentle splash of water and was collected in a beaker. The contents was

*Corresponding author. e-mail: thippeswamyb205@gmail.com 
allowed to settle down for half an hour and then filtered by passing through a single layer of very closely woven white synthetic cloth. The debris, spores and sporocarps of VAM fungi was retained on the cloth mesh. The cloth mesh with the spores / sporocarps was kept on the petriplate along with little amount of water and observed under stereo binocular dissecting microscope at 10X and 40X magnification.

\section{Colonization of Am fungi}

Root samples were subjected to root clearing and staining technique (Phillips and Hayman,1970) in which the root samples were cut into $1 \mathrm{~cm}$ bits and then cleared with $10 \% \mathrm{KOH}$ for $20 \mathrm{~min}$ then it was rinsed with distilled water ant cleared with $0.5 \mathrm{~N} \mathrm{HCl}$ for $3 \mathrm{~min}$, rinsed with water and stained with $0.05 \%$ trypan blue in Lactophenol. About 100 root segments were analysed and percentage of colonization was calculated using the formula.

Root colonization $=\frac{\text { Number of colonized segments }}{\text { Total number of segments observed }} \times 100$

\section{Result and discussion}

Soil and root sample from 3 different sites show the presence of AM fungi (Table I).The root samples exhibited varied range of percent colonization (Table II). Highest colonization was found in Gomphrena globosa $\mathrm{L}$ in site 2. Root clearing and staining shows the presence of Arbuscular, large vesicles and hyphae.
1987, Sambadan et al. 1991) and Xeropytic Plants (Lakshman, 1992).

Allen et al. (1995) suggested that both species richness and spore density of AM fungi depend upon the size of the area sampled, season and yearly variations in precipitation and temperature.

Among the agronomicically important plant families, the Leguminosae and Graminae have been found to be good hosts of AM fungi under normal growth conditions.

The existence of functional diversity amongst AM fungi suggests that a combination of several species of fungi could increase the effectiveness of phosphate extraction from soil (Koide and Mosse, 2004).

Communities of AM fungi species varying in composition, number and therefore, in biodiversity occur in ecosystems (Jonnson, et al, 1992).

\section{Conclusion}

Plants belonging to amaranthaceae family are considered as non-mycorrhizal but the present study shows that amaranthaceae members posses AM fungal colonization. Hence few members of amaranthaceae are mycorrhizal.

\section{Table I. AM fungi isolated from plants}

\begin{tabular}{lccc}
\hline Plant & Site 1 & Site 2 & Site 3 \\
\hline Gomphrena globosa $\mathrm{L}$ & Glomus $\mathrm{sp}$. & Glomus badium & Acaulospora delicata \\
& & Acaulospora delicata & \\
Amaranthus dubius Mart ex Thell & Glomus $\mathrm{sp}$. & Acaulospora delicata & Glomus badium \\
\hline
\end{tabular}

\section{Percentage of colonization of AM fungi}

\begin{tabular}{lccc}
\hline Plant & Site 1 & Site 2 & Site 3 \\
\hline Gomphrena globosa L & $72 \%$ & $72 \%$ & $68 \%$ \\
Amaranthus dubius & $88 \%$ & $92 \%$ & $90 \%$ \\
Mart ex Thell & & & \\
\hline
\end{tabular}

Economically beneficial plants in which high and diverse occurrence of AM fungi have been noted include fruit plant (Abul-Hasan and Khan, 2004), medicinal plants (AbdulKhaliq and Janaradhanan, 1994, Bukhari et al., 2003), aromatic plants (Govind rao et al. 1987), trees (Nalini et al.

\section{References}

Abul-Hasan Khan MN (2004), Status of arbuscular mycorrhizae in mango in six districts of uttar pradesh. Mycorrhizae news. 16: 16-18.

Abdul-Khaliq and Janaradhanan KK (1994), Variartion of native VA-mycorrhizal association on cultivated species on mint. Symbiosis. 16: 75-82.

Allen EB, Allen MF, Helm DJ, Trappe JM, Molina R and Ricon E (1995), Patterns and regulation of mycorrhizal 
plant and fungal diversity. Plant soil. 170: 47-62.

Bukhari MJ, Khade SW, Jaiswal V, Gaonkar UC and Rodrigues BF (2003), Arbuscular mycorrhizal (AM) status of tropical medicinal plants: A field survey of arbuscular mycorrhizal fungal association in herbs. Plant Archieves. 3: 167-174.

Gerdmann JW and Nicolson TH (1963), Spores of mycorrhizal endogone species extracted from soils by Wetsieving and decanting. Trans. Br. Mucol. Soc.46: 35244.

Govind Rao YS, Suresh CK, Suresh NS and Bhagyaraj DJ (1987), Vesicular arbuscular mycorrhizae in aromatic plants. Curr:Res. 16: 55-57.

Harley JI and Harley FI (1987), A Checklist of mycorrhiza in the British flora. New Phytol. 105 : 1-102.

Johnson CR, Copeland PJ, Croeskton RK, Pfleger FL (1992), Mycorrhizae: Acaulospora sp. possible explanation for yield decline associated with continuous cropping of corn and soyabean. Agron. J. 84: 387-390.

Lakshman HC (1992), Occurrence of VA-mycorrhizal fungi in some hydrophytic and xerophytic plants of Dharwad district in Karnataka. J. Natl. Cons. 1: 825-829.
Koide RT and Mosse B (2004), Acaulospora sp. history of research on arbuscular mycorrhiza. Mycorrhiza. 14: 145-163.

Meada MI (1954), The meaning of mycorrhiza in regard to systematic botany. Ka Amoto J. Sci. Ser. B3: 57-84.

Nalini PA, Byra Reddy MS and Bagyaraj DJ (1987), VA spore types present in the root zone of Leucaena leucocephala (Lam.) De. Mycorrhiza Round Table proceedings of Workshop, Jawaharlal Nehru University, New Delhi, pp.129-136.

Phillips JM and Hayman DS (1970), Improved procedures for cleaning roots and staining, Parasitic and Vesiculararbuscular mycorrhizal fungi for the rapid assessment of infecting. Trans. Br. Mycol. Soc. 55: 158-161.

Sambadan K, Raman N and Kannan K (1991). Association of AM fungi with Casuarina equisetifolia at different soil types in Tamil Nadu, India. In: (Abstract) Proceedings of the Second Asian conference on mycorrhiza, (Eds.) I. Soerianegara and Supriyanto, pp. 61-65.

Received: 04 October 2012; Revised: 13 October 2013; Accepted: 17 December 2013. 